\title{
痛風・高尿酸血症の病態と治療
}

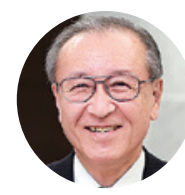

藤森 新

\section{Key words 尿酸排泄機構，HPFS，無症候性高尿酸血症，キサンチン酸化酵素阻害薬，治療ガイドライン}

\section{はじめに}

我が国において, 1950年頃までは希少疾患で あった痛風は, 食生活の欧米化と飽食の時代を 経て患者数は増加の一途をたどり,「国民生活基 礎調査」（厚生労働省，2013）によると100万 人を超え, 痛風関節炎を発症していない無症候 性高尿酸血症の人は 1,000 万人に達すると推計 されている. 1950～1960年代に開発され，痛 風治療に用いられたプロベネシドやアロプリ ノール, さらには1970年代に登場したベンズ ブロマロン等, 優秀な尿酸降下薬によって痛風 関節炎のコントロールが可能となり, 痛風の治 療体系は完成したかに思われていたが, ベンズ ブロマロンの登場以降, この領域では新規薬剤 の開発が進まなかったこともあり, 診療・研究 の両面において新知見がそしい時期が続いたこ ともあった。しかしながら,フェブキソスタッ トに代表される新規尿酸降下薬の開発に伴い, 2000 年前後から本領域での研究が再び活発に なっている.
従来, 4 component theoryで説明されていた 腎臓での尿酸排泄機構が 2002 年の尿酸トラン スポーター（urate transporter 1 : URAT1）の同 定に始まる各種トランスポーターの発見によっ て分子レベルで説明できるようになった（図 1).さらに, 観察研究を主とする多くの疫学研 究やモデル動物を用いた精力的な基礎的研究を 通じて, 高尿酸血症は痛風関節炎のみならず, 腎障害, 尿路結石, 高血圧, 虚血性心疾患, 心 房細動, 心不全, 脳血管障害, 動脈硬化, メタ ボリックシンドローム等種々の病態とも関係が 深いことが明らかにされ, 無症候性高尿酸血症 に対する薬物適応についても, 腎障害や心血管 障害の発症・進展に一次エンドポイントを置い た介入研究が進んできている。

\section{1. 痛風・高尿酸血症に関与する 遺伝素因と生活習慣}

血清尿酸值はプリン代謝経路による尿酸生成 と体外への尿酸排泄のバランスによって一定に 


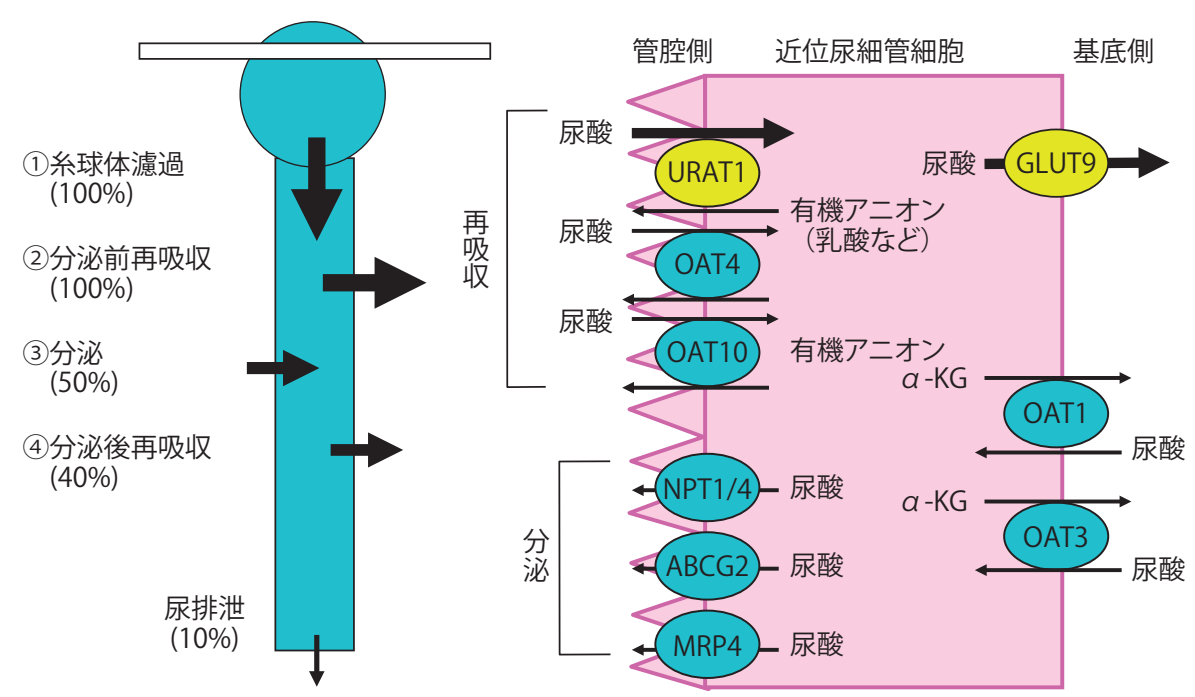

図 1 尿酸排泄機構

4 component 機構と現在想定されている尿酸トランスポーター

維持されており，このバランスが破綻すると高 尿酸血症がもたらされる。尿酸排泄は主として 腎臓で行われ, 尿酸排泄機構はトランスポー ターの組み合わせで説明されるようになった。 尿酸は腎糸球体から $100 \%$ 濾過され，尿細管腔 で再吸収と分泌が繰り返され，最終的には濾過 した尿酸のおよそ10\%が尿中に排泄される.尿 酸の再吸収には腎近位尿細管に発現している URAT1 と血管側に発現しているglucose transporter 9 (GLUT9) の関与が主体で, 分泌は尿細 管腔に発現しているATP-binding cassette (ABC) トランスポーターである $A B C G 2$ 遺伝子の役割が 大きい（図 1)。遺伝子変異の結果として，この ABCG2 の機能が高度に低下していると, 痛風発 症の危険度が約25倍高まり, ABCG2の機能が低 いほど痛風の発症年齢が若いことが報告されて おり, ABCG2の機能異常は痛風の遺伝性素因の 1つと考えられる。また, ABCG2 は腎臓のみな らず, 肝臓や腸管にも発現しており, 尿酸の腎 外処理として重要な役割を果たしている ${ }^{1)}$.

米国に抽て痛風を発症していない約 5 万人 の男性を対象に, どのような生活習慣が痛風を
発症させやすいかを 12 年間に亘って調査した， 大規模前向き調査である Health Professionals Follow-up Study（HPFS）の解析結果が報告され ている。この調査によって, 肥満と体重増加, アルコール飲料 (特にビール) や肉類, 魚介類 (高プリン体食), また, 清涼飲料等を多く摂取 する食習慣は, 痛風の発症リスクを $1.4 \sim 2.5$ 倍 高めること, 反対に瘦せと体重減少, 乳製品( 低 プリン体食）やワインの適量摂取, コーヒーを よく飲む習慣等は, 痛風の発症リスクを20～ 60\%低減させることが明らかになった2)(表 1). また, 同様の食習慣が高尿酸血症に関与するこ とも同じグループの横断研究によって明らかに されている21.

\section{2. 高尿酸血症のリスク}

痛風関節炎は関節内に析出した尿酸塩結晶に よって引き起こされる急性関節炎である.この ことから, 高尿酸血症は尿酸の溶解限界である 血清尿酸值が $7.0 \mathrm{mg} / \mathrm{dl}$ を超えた状態 (血清尿酸 值 $>7.0 \mathrm{mg} / \mathrm{dl}$ ) と定義される ${ }^{3)}$. 健常男性を対 
表 1 痛風と食生活に関するエビデンス (HPFS)

\begin{tabular}{|c|c|}
\hline 痛風を発症させやすい生活習慣 & 痛風を発症させにくい生活習慣 \\
\hline $\begin{array}{l}\text { 1，肥満；Arch Intern Med， } 2005 \\
\text { BMI } 25 \text { 以上 (1.65 2.3) }\end{array}$ & $\begin{array}{l}\text { 1，やせ； } \\
\text { BMI } 21 \text { 未満 (0.48) }\end{array}$ \\
\hline $\begin{array}{l}\text { 2，体重増加；Arch Intern Med，2005 } \\
13.5 \mathrm{~kg} \text { 以上（1.72） }\end{array}$ & $\begin{array}{l}\text { 2，体重減少； } \\
4.5 \mathrm{~kg} \text { 以上 }(0.61)\end{array}$ \\
\hline $\begin{array}{l}\text { 3，飲酒；Lancet，2004 } \\
\text { 純アルコールで } 50 \mathrm{~g} \text { 以上/日 (2.53) } \\
\text { ビール 2 缶 }(700 \mathrm{ml} \text { ) 以上/日 (2.51) }\end{array}$ & $\begin{array}{l}\text { 3，ワイン； } \\
\text { ワイングラス 1 杯/日 (0.82) }\end{array}$ \\
\hline $\begin{array}{l}\text { 4，高プリン体食；N Engl J Med，2004 } \\
\text { 肉類攝取 }(1.41) \\
\text { 魚介類摂取 }(1.51)\end{array}$ & $\begin{array}{l}\text { 4，低プリン体食； } \\
\text { 乳製品摂取 }(0.56)\end{array}$ \\
\hline $\begin{array}{l}\text { 5，清涼飲料；BMJ，2008 } \\
2 \text { 缶以上/日 (1.85) }\end{array}$ & $\begin{array}{c}\text { 5，コーヒー ; Arthritis Rheum， } 2007 \\
\text { コーヒー4 5 杯/日 (0.60) } \\
\text { 6杯/日以上 }(0.41)\end{array}$ \\
\hline
\end{tabular}

表 2 尿酸と各種疾患との関係を検討した観察研究のメタ解析

\begin{tabular}{|c|c|c|c|c|}
\hline & 論文件数 & 対象数 & $\begin{array}{l}\text { 相対リスク } \\
\text { (補正) }\end{array}$ & 参考文献 \\
\hline CKD の発症 & 15 & 99,205 & $1.22 *$ & PLoS One 9 (6) : e100801. 2014 \\
\hline 高血圧の発症 & 18 & 55,607 & 1.41 & Arthritis Care Res $63: 102,2011$ \\
\hline 冠動脈疾患の発症 & 13 & 69,898 & 1.09 & Arthritis Care Res $62: 170,2010$ \\
\hline 冠動脈疾患死 & 13 & 333,099 & 1.16 & Arthritis Care Res $62: 170,2010$ \\
\hline 脳卒中の発症 & 16 & 238,449 & 1.47 & Arthritis Rheum 61: 885, 2009 \\
\hline 脳卒中死 & 16 & 238,449 & 1.26 & Arthritis Rheum $61: 885,2009$ \\
\hline 心房細動の発症 & 7 & 146,792 & 1.8 & Int J Cardiol 184 : 699-702, 2015 \\
\hline 2 型糖尿病の発症 & 11 & 42,834 & $1.11 *$ & Diab Care 32 : 1737-1742, 2009 \\
\hline
\end{tabular}

象とした代表的なコホート研究によると, 無症 候性高尿酸血症のうち, 血清尿酸值が $8.0 \mathrm{mg} /$ $\mathrm{dl}$, 特に $9.0 \mathrm{mg} / \mathrm{dl}$ を超えたものは, それ以下に 比べて将来の痛風関節炎の発症率が有意に高い ことが報告されている。慢性腎臓病（chronic kidney disease : CKD), 高血圧, 冠動脈疾患の 発症ないしは冠動脈疾患死, 脳卒中の発症ない しは脳卒中死, 心房細動の新規発症, 2 型糖尿病 の発症等と尿酸の関係を検討している観察研究 を集めたメタ解析 (総数42,834 402,997例) で は, 血清尿酸值が高い場合にこれらのリスクが 1.09〜1.8 倍高まることが示されている4)(表 2).
尿酸降下薬を投与して腎障害の進展を抑制で きるかを検討した介入研究もいくつか報告され るようになり，9論文580例を対象としたメタ 解析では 0.25 24 力月に亘る尿酸降下薬の投 与によって血清クレアチニン值の増加が抑制さ れていることが示されている5)(図2).さらに, アロプリノールによる血圧への影響も検討され て扣り,介入研究 10 論文 (総数 738 例) のメタ 解析では，アロプリノール投与群では収縮期血 圧が $3.3 \mathrm{mmHg}$, 拡張期血圧が $1.3 \mathrm{mmHg}$ 低下す ることが示されている ${ }^{6)}$.

心不全患者では, 血清尿酸值が高いほど血管 


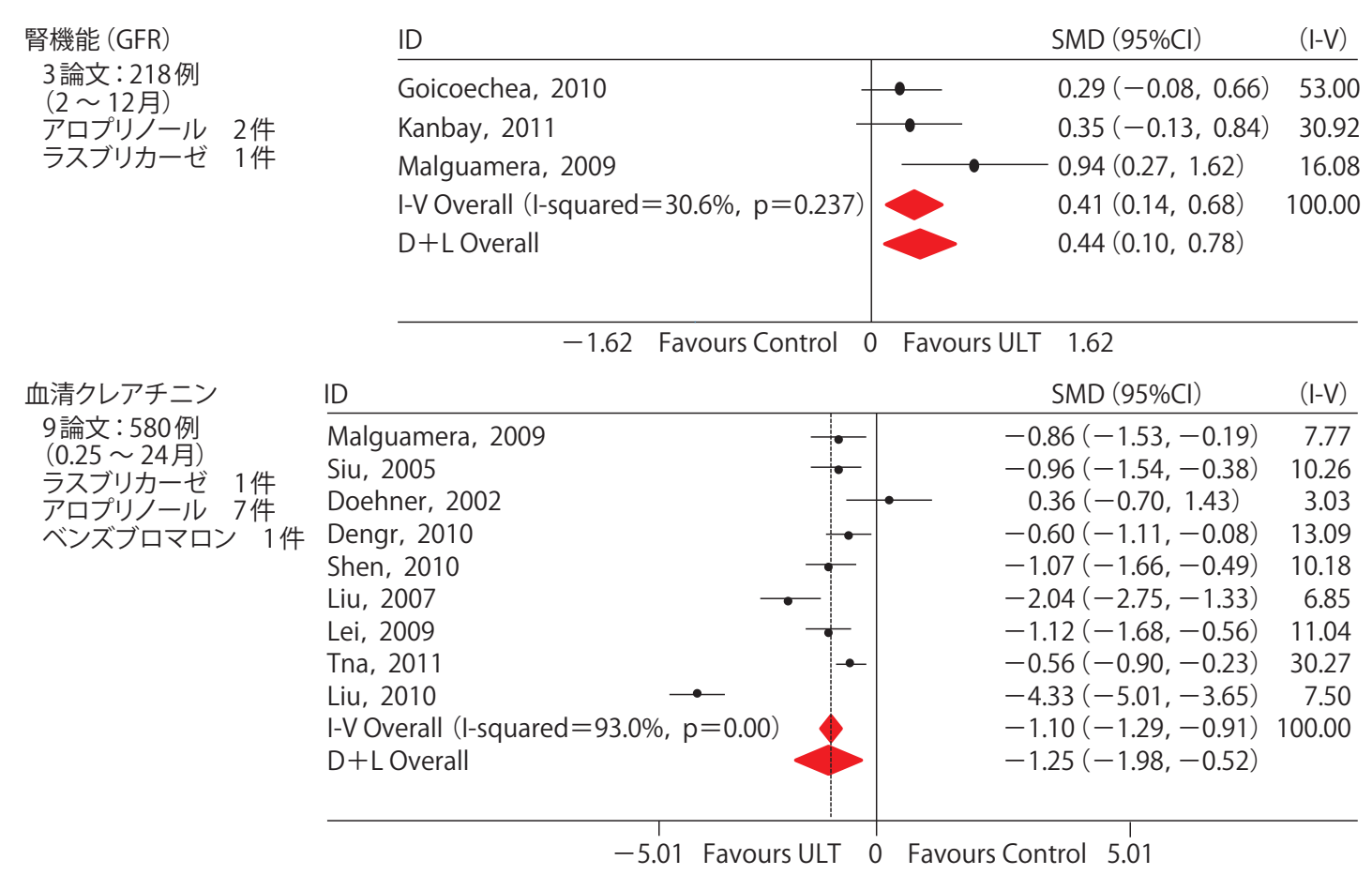

図 2 尿酸降下による腎機能への影響: メタ解析

内皮機能が障害されやすく，アロプリノール投 与はこれを好転させる ${ }^{7)}$. 尿酸はプリン代謝分 解経路の最終段階に作用するキサンチン酸化酵 素によって生成する，この酵素は尿酸を生成さ せると同時に活性酸素も産生させ, 生体内の酸 化ストレスを六進させ，血管内皮機能障害をも たらす. また, URAT1を介して血管内皮細胞に 取り込まれた尿酸は, 細胞内において酸化スト レス発生や核内転写因子の活性化をもたらし, 炎症性細胞浸潤や血管平滑筋増殖を引き起こ し, 心血管合併症を引き起こすと推察されてい る.この仮説に従えば, キサンチン酸化酵素阻 害薬によって血清尿酸值を低下させることで, 心血管合併症を抑制できる可能性があるが，尿 酸降下治療と心血管イベントを検討した介入研 究のメタ解析 (総数 27,313 例) では, 尿酸降下 の有用性は示されていない8).

\section{3. 痛風・高尿酸血症の管理}

痛風関節炎は激烈な痛みを生じ，しばしば歩 行不能となる等, 患者のQOL (quality of life) を 低下させる. 従って, 痛風関節炎の治療はでき るだけ速やかに患者の愁訴を軽減させることに 主眼が置かれる. 我が国のガイドラインでは, 痛風発作の予感期にコルヒチンを 1 錠 $(0.5 \mathrm{mg})$ に限って使用し, 極期に限ってはNSAIDs （non-steroidal anti-inflammatory drugs）を常用 量の 2〜3 倍多く投与するNSAIDsパルス療法が 推奨されている3 ${ }^{3)}$ しかしながら, 欧米のガイ ドラインでは, 痛風関節炎の治療として, コル ヒチン少量投与, NSAIDs, 副腎皮質ステロイド の3 種類の治療法から, 患者の状態に応じた選 択が勧められており, ガイドラインによって違 いがみられる、いずれのガイドラインも, 痛風 関節炎の誘発につながる血清尿酸值の変動を最 


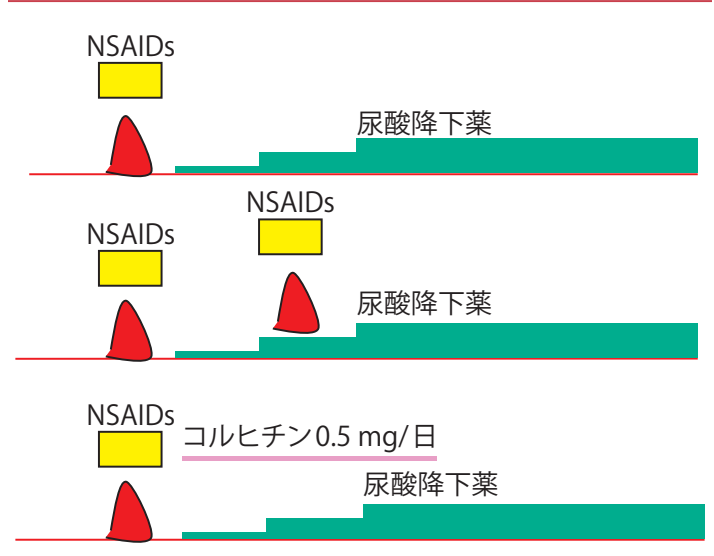

図 3 痛風発作時と痛風間欠期の治療

小限にとどめるために, 尿酸降下薬の投与は少 量から開始すべきであると勧めている，尿酸降 下薬の選択については, 欧米のガイドラインは 尿酸生成抑制薬を第一選択薬に推奨している が, 我が国のガイドラインは病型に即した尿酸 降下薬の選択を推奨している。すなわち, 尿酸 排泄低下型には尿酸排泄促進薬を, 尿酸産生過 剩型には尿酸生成抑制薬を選択するものであ る ${ }^{3)}$. このような選択法が推奨されたのは, 長 年, 尿酸生成抑制薬はアロプリノールしか使用 できず，腎臓排泄性の薬剤であるアロプリノー ルはその活性代謝産物のオキシプリノールが尿 酸排泄機構で処理されるため, 尿酸排泄低下型 では血中のオキシプリノール濃度が増加して重 篤な副作用を引き起こす懸念があったためであ る. 尿酸排泄低下型の患者を尿酸生成抑制薬で 治療しても血清尿酸值の低下は遜色なくもたら されることは, 海外と我が国の臨床試験で証明 されている99.

少量の尿酸降下薬で尿酸降下療法を開始して も痛風関節炎が起こることがあるが, その際に は尿酸降下薬は中止せずにNSAIDsを多めに投 与し，関節炎の鎮静化を図るとよい（図3).ま た，このような痛風関節炎の誘発が危惧される 場合は, しばらくコルヒチン 1 錠を尿酸降下薬

\section{表 3 高尿酸血症・痛風の治療ガイドライン第 3 版} 7 つの CQ

1. 急性痛風性関節炎の発作を起こしている患者におい て，ステロイド・NSAIDs・コルヒチンは無投薬に比 して推奨できるか?

2. 腎障害を有する高尿酸血症の患者において，尿酸降 下薬は無投薬に比して推奨できるか？

3. 高尿酸血症合併高血圧患者において，尿酸コントロー ル薬は無投薬に比して推奨できるか？

4. 痛風結節を有する患者において，薬物治療により血 清尿酸値を $6 \mathrm{mg} / \mathrm{dl}$ 以下にすることは血清尿酸值に 目標値を設けない場合に比して推奨できるか？

5. 高尿酸血症合併心不全患者において，尿酸降下薬は 無投薬に比して推奨できるか?

6. 痛風発作が頻発する患者において, コルヒチンカバー を長期間使用することは短期間使用することに比し て推奨できるか？

7. 無症候性高尿酸血症の患者において，食事指導は食 事指導をしない場合に比して推奨できるか?

と共に併用投与するコルヒチンカバーが有用で ある（図3)。薬物治療導入後は，血清尿酸值の 推移をみながら，また，副作用の発現に注意し ながら, 1〜2力月毎に増量し, 沈着している尿 酸塩結晶の融解除去を達成するために, 血清尿 酸值 $6.0 \mathrm{mg} / \mathrm{dl}$ 以下を維持できる薬用量を決め, その量を維持量として長期に亘って投与するこ とが重要である。

\section{4. 高尿酸血症・痛風の 治療ガイドライン第 3 版}

2018年中の発行を目指し,「高尿酸血症・痛 風の治療ガイドライン第 3 版」の改訂作業が鳥 取大学久留一郎教授の下で進められている ${ }^{10)}$. 本ガイドラインでは, 通常の教科書的記述に加 え, 7つのクリニカルクエスチョン (clinical question：CQ）を設定し，各委員がCQに対して システマティックレビューを行い, その推奨度 を決めるべく作業中である（表3）。第2 版が発 行された2010年以降, 観察研究にとどまらず, ランダム化比較試験（randomized controlled 
trial：RCT）を含む介入試験が多く行われるよう になり，それらをまとめたメタ解析も報告され 始めている，7つのCQのなかには，腎障害，高 血圧，心不全等を合併した高尿酸血症に対する 尿酸降下療法の是非を問うものが含まれてお り，無症候性高尿酸血症に対する薬物治療につ
いて，これまで以上に明確な指針が出されるこ とが期待される。

著者のCOI（conflicts of interest）開示：藤森 新 ; 講演 料 (三和化学研究所)

\section{文献}

1) Ichida $K$, et al : Decreased extra-renal urate excretion is a common cause of hyperuricemia. Nat Commun 3 : $764,2012$.

2）藤森 新：痛風・高尿酸血症. 診断と治療 $101: 1477-1481,2013$.

3）日本痛風・核酸代謝学会ガイドライン改訂委員会編：高尿酸血症・痛風の治療ガイドライン第 2 版，メディカルレ ビュー社, 2010.

4) 藤森 新：無症候性高尿酸血症の治療. 日本臨床 74（増刊9）：272-276, 2016.

5) Wang $\mathrm{H}$, et al : Effects of urate-lowering therapy in hyperuricemia on slowing the progression of renal function : a meta-analysis. J Ren Nutr 23 : 389-396, 2013.

6) Agarwal V, et al : Effect of allopurinol on blood pressure : a systematic review and meta-analysis. J Clin Hypertens 15:435-442, 2013.

7) Kanbay M, et al : Effects of allopurinol on endothelial dysfunction : a meta-analysis. Am J Nephrol 39 : 348356, 2014

8) Zhang T, Pope JE : Cardiovascular effects of urate-lowering therapies in patients with chronic gout : a systematic review and meta-analysis. Rheumatology 56 : 1144-1153, 2017.

9) Yamamoto $\mathrm{T}$, et al : Effects of febuxostat on serum urate level in Japanese hyperuricemia patients. Mod Rheumatol 25 : 779-783, 2015.

10）太田原顕：診療ガイドライン作成の現状. Current Therapy 35 : 622-627, 2017. 